\title{
Phenotypic Characterization of Clostridium Species in Sheep Meat
}

\author{
Mahmoud E. El-Sayed ${ }^{1}$, Islam Z. Mohamed ${ }^{2}$, and Islam M. \\ Khalifa $^{3}$ \\ ${ }^{1}$ Department of Bacteriology, Immunology and Mycology, Faculty of \\ Veterinary Medicine, Suez.Canal University.mezzat05@yahoo.com \\ 2. Animal Health Research Institute, Dokki, Giza \\ islamshereef@yahoo.com \\ 3 Salhia, Sharkia. ekhalifa84@gmail.com (Corresponding author)
}

\begin{abstract}
The existence of Clostridium species in sheep meat has a public health importance. The current preliminary study was aimed to investigate the prevalence of various Clostridium species in sheep meat. Thirty meat samples were randomly collected from butcher's markets at Ismailia province. The collected samples were subjected to the bacteriological examination; moreover, the enumeration of anaerobic count was performed. The total count of anaerobes was $6 \times 10^{3}$ C.F.U./ g; in addition, the prevalence of $C$. bifermentans, $C$. sporogens, $C$. subterminal, and $C$. perfringens was $10 \%$, $43.3 \%, 30 \%, 30 \%$ sheep meat samples, respectively. $C$. perfringens is considered one of the main spoilage organisms of meat leading to contaminations of great amount of decomposed meat, which ending with economic losses; bad hygienic conditions in slaughterhouses are the main cause for meat contamination with Clostridium species, since the gastrointestinal tract of slaughtered animals is their natural habitat, the abattoir processing represent a great source for meat surface contamination by these pathogens.
\end{abstract}

Keywords: C. bifermentans, C. sporogens, C. subterminal, $C$. perfringens, Sheep meat

\section{Introduction}

Meat is an excellent source of high-quality protein and rich in minerals and vitamins which are essential for human health, power and vitality. Meat may affect the public health due to their contamination with spoilage microorganisms which are responsible for objectionable changes as well as the presence of pathogenic organisms which may lead to either food infection or food intoxication (Libby, 
1975; Hanninen, 1980 and FAO/WHO, 1983).

Microbiological quality of fresh meat has been receiving attention all over the world due to the occurrence of significant outbreaks of foodborne illness affecting consumers. Quality maintenance is important not only for consumer health protection but also to assure uniformity in fresh meat shelflife, (Widders, 1995). Meat is considered an important source of proteins and essential amino acids. Due to this rich composition, it offers a highly favorable environment for the growth of pathogenic bacteria. The microbiological contamination of carcasses occurs mainly during processing and handling, such as skinning, evisceration, storage and distribution at slaughter houses and retail establishments (Gill, 1998 and Abdalla et al., 2009).

Anaerobic bacteria such as Clostridia constitute an important group of the microorganisms which are responsible for many public health hazards. They are able to survive the relatively high temperature by production of their resistant spores (Barnes, 1985). Clostridium perfringens is one of such group which has great effect on human health as food poisoning organism. The majority of foodborne diseases caused by $C$. perfringens result from the consumption of meat and meat products (Lynch et al. 2006; Wahl et al. 2013).

The abattoir process is considered the great source of meat surface contamination by $C$. perfringens organisms either internally from animal after slaughtering as postmortem invasion from gastrointestinal tract or externally from contaminated hands, skin of animals, water, soil and processing equipment. Foodborne pathogens are the leading causes of illness and death in developing countries costing billions of dollars in medical care, medical and social costs (Fratmico et al., 2005).

Due to the rising incidence of food borne infections, there is an urgent need for control and/or prophylaxis for food poisoning outbreaks associated with meat. It depends greatly on investigating the causative agents in carcasses, eliminating them to ensure food safety and to protect public health from microbial contamination of food (Al Khaldi et al. 2004 and Albini et al. 2008).

The current preliminary study was aimed to investigate the prevalence of various Clostridium species as well as monitoring the total anaerobic count in sheep meat.

\section{Material and Methods 1- Samples collection:}


A total of 30 Meat samples were randomly collected from butcher's markets at Ismailia province. Samples were collected separately in sterile plastic bags, and then were labeled and given serial numbers. They were kept in an Ice box and transferred quickly to the laboratory with minimum of delay for anaerobic bacteriological examination according to Cruickshank et al., (1975).

2-Processing of collected samples:

a) Preparation of homogenate (ICMSF. 1978).

Twenty five grams of each sample were removed aseptically using a sterile forceps and scissors from different points of the sample then placed in sterile polyethylene bag to which 225 $\mathrm{ml}$ of sterile peptone water $0.1 \%$ were added aseptically; the content was homogenized in a stomacher (MPW.302 Poland) for one minute to provide a dilution of $10^{-1}$ Such homogenate was used for all bacterial investigations.

b) Preparation of serial dilutions:

From the prepared homogenate; 1/10 dilution; $1 \mathrm{ml}$ was taken by a sterile pippete then transferred to a sterile test tube containing 9 $\mathrm{ml}$ sterile peptone water $0.1 \%$ and was shaken well using a test tube shaker to made a dilution of 1/100 using a new sterile pippete $1 \mathrm{ml}$ was transferred from $1 / 100$ dilution to next tube for making a dilution of $1 / 1000$; the process repeated till dilution of $10^{-5}$.

\section{3-Total anaerobic count:}

The enumeration technique was done by Using plate count technique according to Roberts et al. (1995). From each of the prepared dilution $0.1 \mathrm{ml}$ was taken and inoculated into each plate of Reinforced Clostridia agar "RCA" (LAB M23). The inoculums were spread over the entire surface of the agar using a sterile bented glass rod until the inoculum was completely dried. After the agar surface had been appeared to be dried, the plates were overloaded with an additional layer $(10 \mathrm{ml})$ of the melted respective medium at 50 $55^{\circ} \mathrm{C}$, after the solidification of the overlaid layer; all plates were incubated anaerobically in Gas-Pack anaerobic jar (Brewere and Allgeier, 1966) at $37 \mathrm{C}$ for 48 hours. Counting and calculation were recorded.

4- Isolation of Clostridium species (ICMSF. 1978):

The surface of each sample was sterilized by using hot spatula and two bean size pieces were obtained from the deeper parts, then inoculated separately into two tubes of freshly prepared, previously boiled and cooled cooked meat medium. One of the two inoculated tubes was heated 
at $80^{\circ} \mathrm{c}$ for 15 minutes in water bath with a depth of water more than the level of the material in tubes, while the second tube was left unheated. Both tubes were then incubated anaerobically at $37^{\circ} \mathrm{c}$ for $48 \mathrm{hrs}$. A loopful from each unheated tube was streaked onto the surface of $10 \%$ sheep blood agar with neomycin sulphate $(200 \mathrm{mg} / \mathrm{ml})$ for isolation of $\mathrm{C}$. perfringens (Smith and Holdeman. 1968) While, the heated tubes were then streaked on $10 \%$ sheep blood agar plates for isolation of other clostridia. Inoculated plates were immediately incubated anaerobically at $37^{\circ} \mathrm{C}$ for 24 - 48 hrs. After incubation, the anaerobic growth on the blood agar plates was examined macroscopically microscopically. Selected suspected colonies were transferred to tubes of freshly boiled and cooled cooked meat medium and incubated anaerobically at $37^{\circ} \mathrm{C}$ for 24 hours to have a pure culture of isolates for further identification.

\section{5- Identification of Clostridium species:}

Phenotypic characteristics of Clostridium species

Table (1): Phenotypic Identification of Clostridium species:

\begin{tabular}{|c|c|c|c|c|c|c|c|c|c|c|c|c|c|}
\hline & ochemical test & $\frac{\ddot{c}}{2}$ & 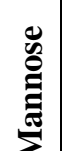 & 离 & $\tilde{\mathfrak{I}}$ & 递泀 & $\bar{\theta}$ & 定 & 岕 & : & 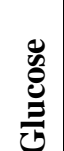 & 苋 & $\frac{\mathscr{b}}{0}$ \\
\hline & C. perfringens & - & + & + & + & + & - & - & + & + & + & + & Co \\
\hline. & C. subterminal & +- & + & + & - & + & - & - & + & + & + & - & To \\
\hline के & C. bifermentans & - & - & $-w$ & + & + & + & - & - & - & + & + & C/so \\
\hline & C. sporogens & - & - & $-w$ & + & + & - & - & - & - & + & + & So \\
\hline$=$ & $\begin{array}{l}\text { Veak reaction } \\
\text { rative reactio } \\
\text { rriable reacti }\end{array}$ & & & & & & & al c & & & & & \\
\hline
\end{tabular}

Isolates were identified the following; Staining, cultural according to Smith and characteristics, Nagler's Holdeman (1968), Willis reaction, and different (1977), Macfaddin (1980), biochemical reactions.

Smith and Williams (1984) as 


\section{Results}

1-The total anaerobic count:

Table (2): Total anaerobic plate count of examined meat samples

\begin{tabular}{|c|c|c|c|}
\hline \multirow{2}{*}{$\begin{array}{c}\text { Sheep- } \\
\text { meat } \\
\text { samples } \\
\mathbf{N}=\mathbf{3 0}\end{array}$} & \multicolumn{3}{|c|}{ Count C.F.U./g } \\
\cline { 2 - 4 } & Min. & Max. & Mean \pm SE \\
\cline { 2 - 4 } & $5.1 \times 10^{3}$ & $8.9 \times 10^{3}$ & $6 \times 10^{3} \pm 2.9 \times 10^{3}$ \\
\hline
\end{tabular}

2-Prevalence of different Clostridium species in the examined sheep meat samples:

Table (3): Prevalence of Clostridium species in the examined meat samples.

\begin{tabular}{|c|c|c|c|c|c|c|c|c|}
\hline \multirow{2}{*}{$\begin{array}{c}\text { Sheep-meat } \\
\text { samples }\end{array}$} & \multicolumn{2}{|c|}{$\begin{array}{c}C . \\
\text { bifermentans }\end{array}$} & \multicolumn{2}{|c|}{$\begin{array}{c}C . \\
\text { sporogens }\end{array}$} & \multicolumn{2}{|c|}{$\begin{array}{c}C . \\
\text { subterminal }\end{array}$} & \multicolumn{2}{|c|}{$\begin{array}{c}C . \\
\text { perferingens }\end{array}$} \\
\hline & No. & $\%$ & No. & $\%$ & No. & $\%$ & No. & $\%$ \\
\hline No $=30$ & 3 & 10 & 13 & 43.3 & 9 & 30 & 9 & 30 \\
\hline
\end{tabular}

\section{Discussion}

Meat may be contaminated with clostridial spores during the slaughtering process and the following handling. Since $C$. perfringens present in the normal flora of intestinal tract of animals. Contamination of the carcass from the intestinal contents, as well as, dust, soil or from workers is virtually unavoidable. In the present work, as illustrated in Table (1), the total anaerobic plate count in the examined meat was $6 \times 10^{3} \pm 2.9 \times 10^{3}$. This result disagrees with the result obtained by Hedia et al., (2009) who detected the total anaerobic plate count in cattle meat samples by higher ratio with a mean value of $2.17 \times 10^{3}$ and
$8.7 \times 10^{3}$ for fore and hind quarter respectively. Furthermore, Hassan (1994) detected the $C$. perfringens count of cattle meat samples with a mean value of $1.17 \times 10^{3}$ +_ 0.35 and $1.90 \times 10^{3}+0.74$ in basateen and moneeb abattoir, respectively. Hedia (2009) mentioned lower prevalence of $C$. perfringens in cattle meat samples for fore quarter with an average of $1.7 \times 10^{2}$ and higher prevalence for hind quarter with an average $2.1 \times 10^{3}$. In camel meat samples, clostridium perfringens were varied from $1 \times 10$ to $2 \times 10^{3}$ with an average $5.2 \times 10^{2} \pm 3.8 \times 10^{2}$ resulted from five $(25 \%)$ positive meat samples for fore quarter, $1.5 \times 10^{2}$ to $3.1 \times 10^{3}$ with an 
average of $1.2 \times 10^{3} \pm 3.6 \times 10^{2}$ obtained from eight (40\%) positive meat samples for hind quarter. Higher ratio were obtained by Hedia et al., (2009) with an average of $2.2 \times 10^{3}$ and $2.4 \times 10^{3}$ for fore and hind quarter respectively. Concerning sheep meat samples, $C$. perfringens count were varied from $2.9 \times 10$ to $2.1 \times 10^{3}$ with an average of $3.9 \times 10^{2} \pm 1.9 \times 10^{2}$ obtained from four (20\%) positive meat samples for fore quarter, $1.4 \times 10^{2}$ to $1 \times 10^{3}$ with an average of $7 \times 10^{2} \pm 3 \times 10^{2}$ resulted from seven $(35 \%)$ positive meat samples for hind quarter. Hassan (1994) reported higher clostridium perfringens count with a mean value of $2.84 \times 10^{3}+0.80 \quad$ and $2.50 \times 10^{3}+\_0.49$ in basateen and moneeb abattoir, respectively.

The recorded data in table (3) demonstrated the prevalence of Clostridium species; the prevalence of $C$. bifermentans, C. sporogens, C. subterminal, and $C$. perfringens was $10 \%$, $43.3 \%, 30 \%, 30 \%$ sheep meat samples, respectively. Most of them have deteriorative effect rather than being disease linked bacteria (Gibbs, 1971). El-Ged and Saad (1985) isolated C.follax, C.sphenoid, C.tertium, C.sporogenes and C.butyrcium from muscle, liver and intestinal content samples while isolated C.perfringens only from intestinal content samples. El-
Seedy et al. (1989) only isolated C.novyi. Nearly similar results were obtained by Hedia et al., (2009) who isolated C.bifermentans, C.sporogens, C.subterminal and C.tertium from cattle and camel meat. Much higher results were recorded by El-Naenaeey (1989) who isolated $C$. perfringens from cattle meat with an incidence of $56.5 \%$. Lower results were obtained by Cohen et al., (2006) who isolated the organism from beef meat with an incidence of $4.5 \%$. While Phillips et al., (2008) failed to detect C.perfringens from retail ground beef samples. These results were in harmony with the results detected by Hedia (2009) who isolated C.perfringens by percentage $20 \% \& 33.4 \%$ from examined cattle raw meat (fore and hind quarter). Much higher result were obtained by Khalid (2013) who isolated C.perfringens from cattle meat samples by percentage $20 \%$. Very high incidence of C.perfringens in ground beef samples (96\%) were detected by Guran et al., (2014). Fahim et al., (2017) detected lower incidence of C.perfringens in raw beef samples (16\%). Concerning the percentage of isolation of $C$. perfringens from camel meat samples were $30 \% \& 45 \%$ for fore and hind quarter, respectively. El-Ged and Saad 
(1985) failed to detect $C$. perfringens from fresh camel meat samples. Similar results were reported by El-Naenaeey (1989) who isolated

C. perfringens from fresh camel meat samples in an incidence of $45 \%$. The result obtained by Kairy (1998) were in harmony with this result who isolated $C$. perfringens from fresh camel meat samples in an incidence of 35\%. Shalaby and El-Mahrouk (2006) obtained nearly similar result , they isolated C.perfringens type $\mathrm{A}$ in an incidence of $33.7 \%$. Higher results were reported by Hedia (2009) who isolated $C$. perfringens by percentage of $46.7 \%$ \& $60 \%$ from examined camel meat (fore \& hind quarter). Much lower incidence of $C$. perfringens in camel meat swab $(2.7 \%)$ were detected by Mohamed, et al. (2010). Similar result obtained by Khalid (2013) who isolated C.perfringens from camel meat samples by percentage of $45 \%$. In sheep meat samples, the percentage of isolation of C.perfringens were $25 \%$ and $40 \%$ for fore and hind quarter, respectively. Higher result obtained by Khalid (2013) who isolated C.perfringens from sheep meat samples in an incidence of $52.5 \%$. Guran et al., (2014) isolated $C$. perfringens from ground sheep meat by very high ratio $(88 \%)$.
The incidence of C.perfringens in camel meat samples was higher than other examined meat samples (cattle and sheep). Moreover, the recorded results showing that the incidence in hind quarters was higher than that of four quarters. This may be attributed to more contamination and excreta near the hind quarters.

In conclusion, $C$. perfringens is considered one of the main spoilage organisms of meat leading to contaminations of great amount of decomposed meat, which ending with economic losses. Poor hygienic procedures in slaughterhouses are the main cause for meat contamination with Clostridium species. Since the natural habitat of $C$. perfringens in the gastrointestinal tract of slaughtered animals, the abattoir processing represents a great source for meat surface contamination by $C$. perfringens organisms.

\section{References}

Abdalla, M.A.; Siham, E.; Suliman, Y.V.H. and Alian, A. (2009):

Microbial

Contamination of sheep

Carcasses at El Kadero Slaughterhouse, Khartoum State, Sud. J. Vet. Sci., Anim. Husb., 48:1-2.
Al Khaldi, S.F., Myers, K.M., Rasooly, A. and Chizhikov, V. (2004): Genotyping of 
Clostridium perfringens toxins using multiple oligonucleotide microarray hybridization. Mol Cell Probes 18, 359-367.

Albini, S., Brodard, I., Jaussi, A., Wollschlaeger, N., Frey, J., Miserez, R. and Abril, $\mathrm{C}$. (2008): Real-time multiplex PCR assays for reliable detection of Clostridium perfringens toxin genes in animal isolates. Vet Microbiol 127, 179-185.

Barnes, E.M. (1985): Isolation methods for anaerobes in foods. Int. J. Food. Microbiol. 2(1/2): 81.

Brewere, J. H. and Allgeier, D. L. (1966): Self-contained carbon dioxide hydrogen anaerobic system. Appl. Microbiol. 14: 985-988.

Cohen, N. Ennaji, H. Hassar, M. and Karib, H. (2006): The bacterial quality of red meat and offal in Casablanca (Morocco), Mol. Nutr Food Res., 50 (6): 557-62.

Cruickshank, R. Duguid, J. P. Marmion, B. R. and Swain, R. H. A. (1975): Medical Microbiology, $12^{\text {th }}$ ED., Living stone, London, New York.

EL-Ged, A. M. S. and Saad, S. M. (1985): Clostridial organisms in slaughtered camels in Egypt. Alex. J. Vet. Sci. 1: 100-105.
El-Naenaeey, E. Y. M. (1989): Ocurrence of C.perfringens type A. Ph. D. thesis (Microbiology), Fac. Vet. Med., Zagazig Univ.

El-Seedy, F.R.; Mervat, A. Barsoum, S.A. and Abd ElGahani, M. (1989): Bacteriological investigations on pyogenic affections in camels. Alex. J. Vet. Sci., 5:252-257.

Fahim A Shaltout,, et al. (2017): "Isolation of Clostridium perfringens from Meat Samples Obtained from the University Students' Hostel". EC Nutrition 9.3 142150.

FAO/WHO (1983): WHO surveillance programmed for control of food born, Inst. Vet. Med. $2^{\text {nd }}$ report. Berlin.

Fratmico, P., Bhunia, A. and Smith, J. (2005): Food borne Pathogens in Microbiology and Molecular Biology, Caister Academic Press, Wymondham, Norfolk, UK., pp.273.

Gibbs, P. A. (1971): The incidence of Clostridia in poultry carcasses and poultry processing plants. B. P. S. 12: 101-110.

Gill, C.O., (1998): Microbiological contamination of meat during slaughter and butchering of cattle, sheep and pigs. In: Davies, A.R., Board, R.G. (Eds.). The Microbiology 
of Meat and poultry, Blackie Academic, London, pp.118-157.

Guran H. S.; Vural A. and Erkan M. E. (2014): The prevalence and molecular typing of Clostridium perfringens in ground beef and sheep meats. J. Verbr. Lebensm. (2014) 9:121128.

Guran H. S.; Vural A. and Erkan M. E. (2014): The prevalence and molecular typing of Clostridium perfringens in ground beef and sheep meats. J. Verbr. Lebensm. (2014) 9:121128.

Hanninen, M.L., (1980): $E$. coli, Y. enterocolitica, C. fetus spp. Jejuni causing food borne disease. A review Soumer Elainl Alkavilet, 86:175.

Hassan, H.S. (1994): Incidence and serotyping of $C$. perfringens among animal slaughtered at Cairo and Giza abattoirs M.V. Sc. Thesis, Meat Hygiene. Fac. Vet. Med, Moshtohour, Zagazig Univ., Benha Branch.

Hedia, I.H.A. (2009): Clostridial species and related organisms in meat and meat products with special reference to keeping quality defects. The degree of Ph.D., Food Control Dept., Benha University.

\section{ICMSF}

Commission Microbiological for
International on Specification (1978):
Microroganism in foods. Univ. Their significance and methods of enumeration, $2^{\text {nd }}$ Ed., Univ. of Toronto Press, Toronto, Canada.

Kairy, D. E. (1998): Studies on C.perfringens in Camel Meat. M. V. Sc. Thesis (Meat Hygiene) Fac. Vet. Med., Cairo Univ.

Khalid A. Alkheraije (2013): Some Characters of $\mathrm{Cl}$. perfringens Isolated from Fresh and Marketed Processed Meat. Vol. 3 No. 2, Article ID: 32839, 5. revised January 15, 2013; accepted February 15, 2013.

Libby, T.A. (1975): Meat Hygiene $4^{\text {th }}$ Ed. Lea and Febiger, Philadelphia, U.S.A.

\section{Lynch M, Painter J, Woodruff} $R$, and Braden C (2006): Surveillance for foodbornedisease outbreaks-United States, 1998-2002. Morbid Mortal Wkly Rep 10:1-34

$\begin{array}{lrr}\text { Macfaddin, } & \text { J.W. } & \text { (1980): } \\ \text { Biochemical } & \text { tests } & \text { for } \\ \text { identification } & \text { of } & \text { medical } \\ \text { bacteria. } & \text { Williams } & \text { and } \\ \text { wikkioing Co. USA. } & \end{array}$ Mohamed, E. M.; Iman I. Suelam and Saleh, M. A. (2010): The presence of toxin genes of Clostridium perfringens isolated from camels and humans in Egypt. Veterinarski Arhiv, Vol. 80 No. 3, Izvorni znanstveni članak. 
Phillips, D. Jordan, D. anaerobic bacteria. I st Ed.201Morriss, S. Jenson. I. and 255. Charles Thomas publisher, Sumner, J. (2008): A national survey of the microbial. Quality of retail raw meats in Australia. J. Food protect. 71 (6): 1232-6.

Roberts, D. Hooper, W. and Greenwood, M. (1995): practical food microbiology. Puteler and tanar, London.

Shalaby and El-Mahrouk, A. M. (2006): Detection of entertoxin C. perfringens type A in camel meat. Vet. Med. J. Giza. 54 (1): 179 - 188.

Smith, L. D. S. and Williams, B. L. (1984): The pathogenic anaerobic bacteria. Charles Thomas publisher. USA.

Smith, L.D. S. and Holdeman (1968): The pathogenic USA.

Wahl E, Rømma S, Granum PE (2013) A Clostridium perfringens outbreak traced to temperature-abused beef stew, Norway, 2012. Eurosurveillance 18:28.

Widders, P.R. (1995): Controlling microbial contamination on beef and lamb meat during processing. Australian Veterinary Journal, Brunswick, V.72, N.6p.208211.

Willis, A. T. (1977): Anaerobic bacteriology, Clinical and Laboratory practice. $3^{\text {th }} \mathrm{Ed}$ Butter Worth, London.

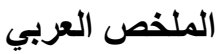

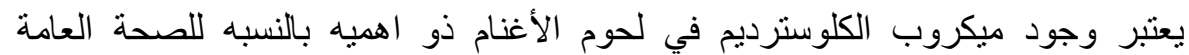

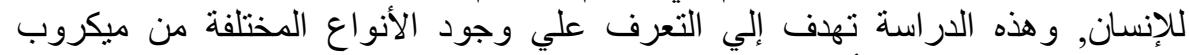

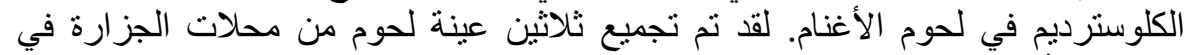

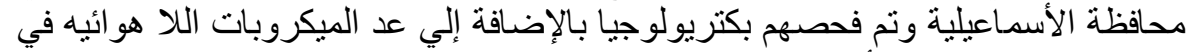
هذه العينات حيث وجد أن العد الكلي للميكروبات اللاهو ائيه كان بمعدل 6×103. عزل ميكروبات

C. bifermentans, C. sporogens, C. subterminal, C. perfringens

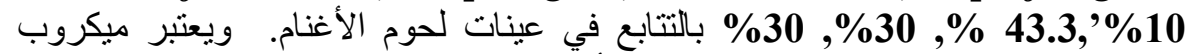

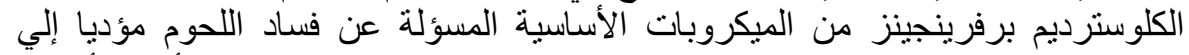

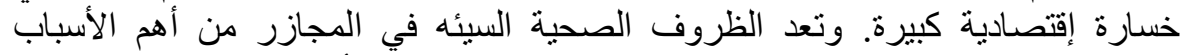

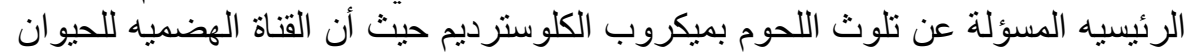

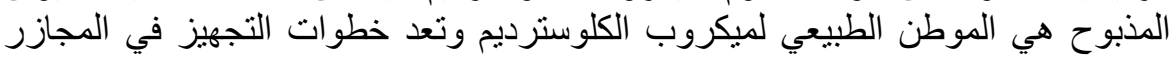

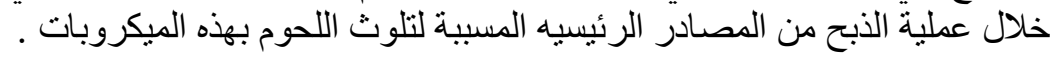

